\title{
Validity Evidence of the Zulliger-SC Test to children's assessment
}

\author{
Lucila Moraes Cardoso ${ }^{1}$ \\ Gabriel Vitor Acioly Gomes' \\ Thalita Sena Vieira \\ ${ }^{1}$ Universidade Estadual do Ceará, Fortaleza, CE
}

\begin{abstract}
Due to the demand for instruments to assess aspects of the personality of children, we aimed find evidence for the validity of the Zulliger test in the Comprehensive System (ZSC). 173 children participated in this study of Fortaleza-CE with ages between 6 years and 11 years and 6 months, 48.5\% were from public schools and $53.1 \%$ female. The children were divided into three age groups, 6 and 7 years, 8 and 9 years and 10 and 11 years. The instruments used were the Zulliger test and the test of Raven's Coloured Progressive Matrices - Special Scale. We made the analysis of descriptive statistics and compared the variables of Zulliger test through the One Way ANOVA test. The significant variables were FQu $(p<0.005)$ and $\mathrm{R}, \mathrm{m}_{\mathrm{a}}, \mathrm{D}, \mathrm{Xu} \%, \mathrm{Na}, \mathrm{Ls}, \mathrm{Fd},(\mathrm{T})$, GHR and $(2)(\mathrm{p}<0.05)$, which contributed with validity evidences of ZSC with children.

Keywords: zulliger $\mathrm{Z}$ test; test validity; children
\end{abstract}

Evidências de Validade do Zulliger-SC para Avaliação de Crianças

\section{Resumo}

Devido à demanda de instrumentos que avaliem aspectos da personalidade de crianças, objetivou-se buscar evidências de validade para o teste de Zulliger pelo Sistema Compreensivo (ZSC). Participaram dessa pesquisa 173 crianças de Fortaleza-CE com a idade entre 6 e 11 anos e 6 meses, sendo 48,5\% de escolas públicas e 53,1\% do sexo feminino. As crianças foram divididas em três faixas etárias, a saber, 6 e 7 anos, 8 e 9 anos e 10 e 11 anos. Os instrumentos utilizados foram o teste ZSC e o teste das Matrizes Progressivas Coloridas de Raven - Escala Especial. Foram feitas as análises de estatística descritiva e a comparação das variáveis do teste ZSC por meio do teste One Way ANOVA. As variáveis significativas foram $\mathrm{FQu}(p<0,005)$ e R, ma, $\mathrm{D}, \mathrm{Xu} \%$, $\mathrm{Na}, \mathrm{Ls}, \mathrm{Fd}$, (T), GHR e (2) $(p<0,05)$, dados que contribuíram com evidências de validade do ZSC com crianças.

Palavras-chave: teste de Zulliger, validade do teste, crianças

Evidencias de validez del Test Zulliger-SC para evaluación de niños

\section{Resumen}

Debido a la demanda de instrumentos para evaluar aspectos de la personalidad de los niños, el objetivo de este estudio fue encontrar evidencias de validez del test Zulliger por el Sistema Comprensivo (ZSC). Participaron de esta investigación 173 niños de Fortaleza-CE con edades entre 6 y 11 años y 6 meses, siendo 48,5\% de escuelas públicas y 53,1\% de sexo femenino. Los niños fueron divididos en tres grupos por edad, a saber, 6 y 7, 8 y 9, 10 y 11 años. Los instrumentos utilizados fueron el test ZSC y el test de las Matrices Progresivas Coloridas de Raven - Escala Especial. Se hicieron análisis de estadística descriptiva y comparación de las variables del test ZSC por medio del test One Way ANOVA. Las variables significativas fueron FQu $(p<0,005)$ y R, ma, D, Xu\%, Na, Ls, Fd, (T), GHR y (2) ( $\mathrm{p}<0,05)$, datos que contribuyeron con evidencias de validez del ZSC con los niños. Palabras-clave: test de Zulliger; validez del test; niños

\section{Introduction}

Psychological assessment tools require frequent studies to verify the adequacy of its psychometric qualities (CFP, 2003). Among these psychometric qualities, there is the evidence of validity of a test, which aims to confirm the degree to which the test measures what it claims to measure and that the proposed interpretations have empirical foundation. Among the strategies to review the evidence of validity of an instrument, there is the evidence based on how it relates with other variables, in which we seek to proof the relationship with other variables, such as in relation to age (AERA, APA \& NCME, 2014).

When considering the search for evidence of validity of a psychological test, we assume that advancing age involves particularities for each stage of the human development. Given that personality is a construct in which this is assumed, it is important to conduct studies that investigate whether psychological instruments to assess this construct can measure the characteristics of the different stages of human development (Nascimento, Pedroso, \& Souza, 2009).

Human development develops in a complex manner and with much influence of social context 
(Vigotski, 2005). Alberto and Santos (2011) stated that the development does not occur linearly, but by the transformation processes that are related to the appropriation of cultural elements.

Recognizing the complexity of child development, researchers in the area of psychological assessment worry about developing studies that demonstrate the validity of psychological tests to assess children. Nunes, Teixeira and Deakin (2010) stated that the number of tests available for use with children is quite limited and stressed the need to invest in research on various instruments. In a recent survey of psychological assessments approved in SATEPSI, are 38 tools that can be used with children (Reppold, Serafini, Ramires, \& Gurgel, 2017). Among the instruments listed by the authors, only four are projective methods.

Synthetically one can say that the Projective Methods aim at assessing aspects of the personality dynamics, proposing to generate information that is unique to the examinee. When dealing with psychometric studies of projective methods, we need to consider some specific challenges (Villemor-Amaral, 2008) and among the strategies to achieve evidence of validity of these methods, the most commonly employed are the evidences of validity based on relationships with other variables, seeking mainly to understand the relation between the indicators (Cardoso \& Villemor-Amaral, 2017).

Even if the total number of these tests isn't great, in Brazil there is ample scientific production of projective techniques that feature adequate psychometric qualities in their studies of validity and reliability (Miguel, 2014). Among the psychological instruments that have been researched, we can mention the Rorschach test in the Comprehensive System (CS) (Exner \& Sendín, 1999; Nascimento, 2010) and the Zulliger-SC Test (Villemor-Amaral \& Primi, 2009). These two instruments are quite similar in their purpose of evaluating the dynamics of personality and in the way of administration and coding. Thus, we highlight the importance of conducting studies with these tests, so they can be used in assessment of children in view of the different characteristics presented throughout a person's development.

Ribeiro, Semer and Yazigi (2011) built normative tables of the Rorschach Comprehensive System for Brazilian children, students from private and public schools. This test was administered to 211 children both male and female, aged between 7 and 10 years, studying in public and private schools in the city of Cuiabá. At the end of the research, the normative tables had 113 variables of the Rorschach Comprehensive System in regard to age and school origin.

Resende, Carvalho and Martins (2012) intended to use the Rorschach Method for Comprehensive System (CS) with children and adolescents, to get the average functioning information of the sample in this test. The study had 201 children and adolescents born in Goiânia-GO, aged between 5 and 14 years, of public and private schools. A specific performance in Rorschach was observed, as expected for each age group. The answers become more elaborate and sophisticated in older children and these subjects show more openness to experiences and a better capacity for observation.

With regard to the Zulliger test Comprehensive System (ZSC), Villemor-Amaral, Pavan, Tavella, Cardoso and Biasi (2016) stated that, since 2003, there is a growing number of studies conducted in Brazil to validate the use of the tool, and most of these studies were performed with an adult sample. However, there are examples of studies that have sought evidence of validity for the use of ZSC with children in Brazil in the literature (Villemor-Amaral \& Quirino, 2013; Tavella \& Villemor-Amaral, 2014; Carvalho, 2015; Biasi \& Villemor-Amaral, 2016; Oliveira, 2016; Villemor-Amaral et al., 2016; Villemor-Amaral \& Vieira, 2016).

Biasi and Villemor-Amaral (2016) sought criterion validity evidence for interpersonal indicators of ZSC. 119 children participated in the first part of the study, female and male students of the fourth, fifth and sixth grade of elementary school in two public schools in a city in the country region of São Paulo, aged between 9 and 14 years. These children responded to a sociogram and, based on this results, for the second part of the study 48 children were selected, divided into two groups; one group of popular children and other less popular children. This division was made based on the number of children who had higher number of preferences and higher number of rejections in the sociogram respectively. The two groups responded to the ZSC and the results showed that the popular children had greater capacity and identification of empathy with human figures and the less popular children showed greater difficulties to identify with human figures. Thus, these data contributed to the validity evidence of ZSC.

Villemor-Amaral et al (2016) searched for new evidences of validity for the use of ZSC with children. The study had a sample of 103 protocols, in which 38 of children aged 6 years old and 65 of 12 year-olds. All Zulliger application protocols were of children from 
public schools in a city in the country side of São Paulo. The results showed that 6-year-old children had highest averages in the use of C', FQ-, $(\mathrm{H}), \mathrm{Fd}, \mathrm{An}$ and DV and children of 12 years of age showed an increase in M, FY, FT, FD and Ls indicators, wherein the variables M, C', FQ-, (H), Fd, An and DV had an intermediate magnitude effect, while the others had a small magnitude effect. The data is consistent to what is expected in terms of emotional and interpersonal development. We also analyzed the interpretive calculations variables and realized that children of 6 years had increased in S-\% Color with FQ-, FQ- Sum, An+Xy, content H Sum, WD with FQ-, WSum6 and X-\%, while at the age of 12 there was an increase with the variables $\mathrm{M}$ with $\mathrm{FQu}, \mathrm{Y}, \mathrm{T}, \mathrm{XA} \%$, WDA $\%$ and $\mathrm{X}+\%$. S- $\%$ indicators, Color with FQ-, FQ- Sum, An + Xy, content H Sum, WD with FQ-, WSum6, X-\%, Y, XA\%, WDA\% and $\mathrm{X}+\%$ had intermediate magnitude of effect. All these variables with intermediate magnitude of effect were increased in the expected groups, according to the meaning of the variables. The discussions made possible to observe typical characteristics of each age group when it comes to the emotional, social and cognitive development of children, which contributed to the evidences of validity of the use of Zulliger the Comprehensive System with children.

Villemor-Amaral and Vieira (2016) searched for evidence of validity for the Zulliger test Comprehensive System in assessing the maturity for interpersonal relationships in children. The authors selected $115 \mathrm{Zul}-$ liger protocols of a database. These protocols were divided into two groups according to age, namely 6 and 12 years, into two groups based on gender. The comparison between groups was performed by Student's t-test. 16 variables were analyzed, namely $\mathrm{H}, \mathrm{Hd},(\mathrm{H})$, (Hd), M, FC, CF, C, A, Ad, (A), (Ad), GHR, PHR, AG and COP. From the analyzes they found good statistical indexes by gender for the variables FC, H, A and Ad and depending on the age for the variables $H,(H), M$, A, (A) and AG. The findings were discussed, with evidence of validity for the use of Zulliger-SC to evaluate the maturity in interpersonal relationships of children.

The studies presented above show the importance of conducting more researches to contribute to the evidence of validity for the use of ZSC with children in Brazil, to expand the sample to other states, since all took place in the southeast. Moreover, it is necessary to carry out studies with a greater variety in the age of the subjects and a larger number of participants. The objective of this study was to seek evidence of validity based on the relation with other variables, to use Zulliger-SC with children from Ceará, comparing the performance obtained according to age.

\section{Method}

\section{Participants}

We established partnerships with public and private schools in the municipality to facilitate the access to participants. The choice of schools was by convenience, favoring schools closer to the research institution. Although we did not do a survey of the socio-cultural conditions of the families of each child, we were informed that the children lived close to the schools, located in the Regional IV of Fortaleza. This region consists of 19 districts and characterized by the average household income of 6 minimum wages and average of 4 people per household (Cartilha da Regional IV, 2011).

173 children participated in this research of Fortaleza-CE, aged between 6 years and 11 years and 6 months. Three groups were organized according to age, namely children of 6 and 7 years, of 8 and 9 years and children aged 10 and 11 years. The first group corresponds to $26 \%$ of the sample, the second to $39.3 \%$ and the third group makes $34.7 \%$ of the total number of children. Of the total, $48.5 \%$ of participants were from public schools and $53.1 \%$ of the sample were female children.

Seeking to control external factors which could interfere with the performance of the participants, the children of the research needed to be attending the scheduled series for their age group, having average or superior score performance in the Raven Progressive Matrices Test and have the Informed Consent Form signed by one guardian to be included in the sample. In addition, we excluded from the sample the children who had been through any psychological or psychiatric treatment, as well as those who were undergoing treatments of this nature at the time of data collection.

\section{Instruments}

The research involved the application of two psychological tools. Those were the Zulliger Test in the Comprehensive System (ZSC) and Raven's Coloured Progressive Matrices - Special Scale.

\section{Zulliger Test in the Comprehensive System (ZCS)}

The Zulliger (ZCS) is a self-expression method which consists of three boards, in which there are 
ambiguous inkblots which act as the test stimulus. The administration and coding was carried out according to the guidelines by Villemor-Amaral and Primi (2009).

The Zulliger in the Comprehensive System has a favorable opinion from the Psychological Test Evaluation System (SATEPSI) for use with adults, since the samples used in the research were formed by subjects belonging to this age group. SATEPSI offers no information on the instructions for use for children, although it is possible to verify that research is being conducted in this direction, according to studies described by Villemor-Amaral and Quirino (2013), Tavella and Villemor-Amaral (2014), Carvalho (2015), Biasi and Villemor-Amaral (2016), Oliveira (2016) and Villemor-Amaral et al. (2016).

\section{Raven's Coloured Progressive Matrices}

Raven's Coloured Progressive Matrices is a psychological instrument that allows the assessment of intelligence. The instrument administration may be individual or collective and the application time is approximately 15 minutes. Taking into consideration that the sample of this study consisted of children aged between 6 years and 11 years and a half, we used the Special Scale version of the Raven's Coloured Progressive Matrices with psychometric studies by Angelini, Alves, Custódio, Duarte and Duarte (1999), favorable for use since 2003, according to the SATEPSI.

\section{Procedures}

Ethical considerations: The data in this article are from the research "Evidências de Validade e Normatização de Métodos Projetivos para Crianças do Nordeste Brasileiro" that was submitted to the Research Ethics Committee (CEP) of Universidade Estadual do Ceará and received authorization to be carried through the CAAE 26205614.1.0000.5534 protocol. After the CEP approval, we resumed contact with the schools that had signed the Term of Institutional Research Consent and had the Term of Free and Informed Consent (TCLE) authorizing the child's participation. The children who were authorized by the parents were called to the research and requested to sign the Term of Free and Informed Consent to confirm their interest in contributing to the study.

Data collection: After the children's acceptance, we asked initial questions to identify sociodemographic and history of search for psychological or psychiatric help. Afterwards, the examiner applied Raven's Coloured Progressive Matrices Test, followed by the ZSC.
It is worth noting that the sessions in which the tests were administered were individual, unique and lasted about 50 minutes.

Data analysis: All protocols concerning the applications of tests with children who met the inclusion criteria in the sample were coded and logged into a database in Excel. We then exported those to the SPSS and made descriptive statistics analysis and comparison of all ZSC variables among the groups. Since the cognitive and affection aspects undergo changes throughout childhood, we decided to group the children by age. Initially two groups were composed, 6 to 8 years, and 9 to 11 years. After making the comparison between the two groups by $t$ Student's test, we found that few variables differ among the groups. Thus, we decided to make the three groups used in this research. By making the comparison of the groups through one way ANOV $A$ test, we observed differences in a greater number of variables and, among these, the quantity of responses (R). The $\mathrm{R}$ variable has a unique importance in the methods of inkblots as it is used to make the ratio and percentage of use of other indicators.

For analysis we considered all the variables that make up the interpretative frameworks as well as the variables required to perform the calculations of some indicators, making a total of 71 variables. As described by Villemor-Amaral and Primi (2009) the interpretative analysis of Zulliger should consider seven frames, namely, Resources and Controls, related to how to handle situations, Affection, which shows the way to process emotional experiences, Interpersonal Relationship, about the way personal relationships are established, Self-perception, which provides information about how a subject sees themselves, Ideation, which is how the individual thinks about what he perceives, Mediation, involving how the subject adapts to information and Processing, which shows how the subject process information.

A need to reset the significance value of $\mathrm{p}<0.05$ to $\mathrm{p}<0.005$ (Benjamin et al., 2017) has been recently reported in the literature, which is a change that contributes to reducing possible errors of type I, ie, wherein the results found may have happened by chance. To estimate the type I error we used the formula proposed by Howell (2009), namely, $1-(1-\alpha)^{c}$, where $\alpha$ is the level of significance and $\mathrm{c}$ is the total of comparisons made. For this study the value of $\alpha=0.005$ and $c=71$. Applying these values in the formula, we have a value of 0.2994 , which represents $29.94 \%$ chance to occur at least one type I error. 


\section{Results}

After comparing the variables of the interpretative frameworks of ZCS's Structural Summary between the three age groups depending, through the OneWay ANOV $A$ test, just FQu was significant at $\mathrm{p}<0.005$ and 10 variables had significant differences at $\mathrm{p}<0.05$ with weak magnitude of effect. Among all variables, five were related to Resources and Control and to the Cognitive Triad, as we show in Table 1.

In Table 1, we see that children aged 6 and 7 years were less inclined to productivity $(\mathrm{R})$ when compared to older children. Children of this group also showed a less practical and concrete way to grasp the reality in answering the task (D) when compared with 8 and 9 year olds and a smaller number of unusual responses $(\mathrm{FQu})$ in relation to children of 10 and 11 years, suggesting a less subjective way of understanding the facts $(\mathrm{Xu} \%)$. The group of children aged 10 and 11 years showed a lower rate of unintentional mental activity in relation to the group of children 8 and 9 years $\left(\mathrm{m}_{\mathrm{a}}\right)$.
In addition to the variables mentioned, we noted that six Structural Summary variables related to affection and Interpersonal Relationship showed $\mathrm{p}<0.05$. The data are shown in Table 2.

With the data shown in Table 2, we see that children of 6 and 7 years of age were less likely to social isolation or avoidance of social contacts ( $\mathrm{Na}$ and $\mathrm{Ls}$ ) compared to older children. We also found that children in this group tend to have a good representation of the human (GHR) showed a diminished and less capacity to put themselves in someone else's place (2) in comparison to other groups of children. The children in the group of 8 and 9 years had a lower dependent behavior index $(\mathrm{Fd})$ when compared to children of 10 to 11 years old. A greater need for physical contact and looking for help in other people was seen in children of 10 to 11 years $(\mathrm{T})$ compared with 8 and 9 years old.

\section{Discussion}

Considering the values suggested by Benjamin et al. (2017), the only significant variable in this study to

Table 1

Significant Differences of the variables Resources and Control and Cognitive Triad of Zulliger by Age

\begin{tabular}{|c|c|c|c|c|c|c|c|}
\hline Variable & Age & $\mathrm{N}$ & $\mathrm{M}$ & SD & $F$ & $\mathrm{p}$ & $\mathrm{eta}^{2}$ \\
\hline \multirow[t]{3}{*}{$\mathrm{R}$} & 6-7 years & 45 & 6.47 & 1.829 & 4.808 & 0.009 & 0.054 \\
\hline & $8-9$ years & 68 & 7.78 & 2.330 & & & \\
\hline & $10-11$ years & 60 & 7.52 & 2.474 & & & \\
\hline \multirow[t]{3}{*}{ Sum $\mathrm{m}_{\mathrm{a}}$} & 6-7 years & 45 & 0.11 & 0.318 & 3.579 & 0.030 & 0.040 \\
\hline & $8-9$ years & 68 & 0.19 & 0.432 & & & \\
\hline & $10-11$ years & 60 & 0.03 & 0.181 & & & \\
\hline \multirow[t]{3}{*}{ Sum D } & $6-7$ years & 45 & 4.22 & 1.999 & 4.446 & 0.013 & 0.050 \\
\hline & $8-9$ years & 68 & 5.41 & 1.839 & & & \\
\hline & $10-11$ years & 60 & 5.12 & 2.450 & & & \\
\hline \multirow[t]{3}{*}{ Sum FQu } & $6-7$ years & 45 & 1.69 & 1.635 & 5.624 & 0.004 & 0.062 \\
\hline & $8-9$ years & 68 & 2.41 & 1.528 & & & \\
\hline & $10-11$ years & 60 & 2.73 & 1.645 & & & \\
\hline \multirow[t]{3}{*}{$\mathrm{Xu} \%$} & 6-7 years & 45 & 0.26 & 0.218 & 4.086 & 0.018 & 0.046 \\
\hline & $8-9$ years & 68 & 0.31 & 0.174 & & & \\
\hline & $10-11$ years & 60 & 0.37 & 0.175 & & & \\
\hline
\end{tabular}


Table 2

Significant differences of the variables Relationship and Self-image on Zulliger by Age

\begin{tabular}{|c|c|c|c|c|c|c|c|}
\hline Variable & Age & $\mathrm{N}$ & $\mathrm{M}$ & SD & $\mathrm{F}$ & $\mathrm{p}$ & eta $^{2}$ \\
\hline \multirow[t]{3}{*}{ Sum $\mathrm{Na}$} & 6-7 years & 45 & 0.11 & 0.318 & 3.139 & 0.046 & 0.036 \\
\hline & 8-9 years & 68 & 0.29 & 0.490 & & & \\
\hline & $10-11$ years & 60 & 0.33 & 0.542 & & & \\
\hline \multirow[t]{3}{*}{ Sum Ls } & 6-7 years & 45 & 0.00 & 0.000 & 3.601 & 0.029 & 0.041 \\
\hline & 8-9 years & 68 & 0.15 & 0.396 & & & \\
\hline & $10-11$ years & 60 & 0.07 & 0.252 & & & \\
\hline \multirow[t]{3}{*}{ Sum Fd } & 6-7 years & 45 & 0.24 & 0.570 & 3.614 & 0.029 & 0.041 \\
\hline & 8-9 years & 68 & 0.07 & 0.359 & & & \\
\hline & $10-11$ years & 60 & 0.28 & 0.490 & & & \\
\hline \multirow[t]{3}{*}{ Sum $T$} & 6-7 years & 45 & 0.02 & 0.149 & 4.429 & 0.013 & 0.050 \\
\hline & 8-9 years & 68 & 0.00 & 0.000 & & & \\
\hline & $10-11$ years & 60 & 0.13 & 0.430 & & & \\
\hline \multirow[t]{3}{*}{ Sum GHR } & 6-7 years & 45 & 1.13 & 0.894 & 4.009 & 0.020 & 0.045 \\
\hline & $8-9$ years & 68 & 1.68 & 0.969 & & & \\
\hline & $10-11$ years & 60 & 1.57 & 1.170 & & & \\
\hline \multirow[t]{3}{*}{ Sum (2) } & 6-7 years & 45 & 2.49 & 1.502 & 4.438 & 0.013 & 0.050 \\
\hline & $8-9$ years & 68 & 3.34 & 1.689 & & & \\
\hline & $10-11$ years & 60 & 3.35 & 1.725 & & & \\
\hline
\end{tabular}

distinguish the groups was FQu (Table 1), which is used to calculate $\mathrm{Xu} \%$. These responses, while not common, do not represent perceptual distortions of reality and suggest a more idiosyncratic way that the subject understands the facts (Exner \& Sendín, 1999; Villemor-Amaral \& Primi, 2009). The frequency of such responses was lower in the verbalizations of children aged 6 to 7 years compared to 10 and 11 years, which can be explained by the fact that these children still limit their perceptions to what was presented to them in the home environment. Moreover, the increase in FQu, as the childrens' age progress, shows an adequate perception of the stimuli without being conventional, ie, it is a more subjective way to analyze the facts (Exner \& Sendin, 1999).

By observing the other variables $\left(\mathrm{R}, \mathrm{D}, \mathrm{Xu} \%, \mathrm{~m}_{\mathrm{a}}\right.$, $\mathrm{Na}$, Ls, GHR, (2),Fd and T) that obtained a significance level of $p<0.05$ and weaker magnitude effect, we found that the same findings corroborate the scientific literature on Projective Methods. Thus, we decided to also discuss these results.

Based on the data presented in Table 1, one can see that the variable $\mathrm{R}$ was diminished in the group of children ages 6 to 7 years when compared with the group of $8-9$ years $(p=0.009)$. According to Villemor-Amaral and Primi (2009), $\mathrm{R}$ is related to productivity and capacity to produce ideas. In this case, the fact that $\mathrm{R}$ has been decreased in the lower age group can also refer to a yet reduced ability to produce associations.

A study by Ribeiro et al. (2011) with the Rorschach-CS also found lower $\mathrm{R}$ average for children 7 years of age compared to those who were older. This data is expected, since children have less life experience 
and still limited possibilities of association. Children of 6 and 7 years are beginning the process of schooling and possibly tend to be less likely to produce responses.

The school has an important role in child development, helping in stimulating the formation of concepts in the children and development of verbal thought (Vigotski, 2007a, apud Alberto \& Santos, 2011). This typical development characteristic can justify the performance quite similar between children aged 8 and 9 years with 10 and 11 years, considering that children from these groups have attended school considerably longer when compared to children of 6 and 7 years.

In Table 1 we also observe that $\mathrm{m}_{\mathrm{a}}$ was decreased in children aged 10 and 11 years. Responses $m_{a}$ relate to unintentional ideation processes and the presence of this determinant is linked to stress, situations that cause conflicts or tensions that tend to disappear when the problem is resolved (Nascimento, 2010).

Variables D, FQu and $\mathrm{Xu} \%$ were also significant (Table 1). About D, Exner and Sendín (1999) stated that this response means that the subject tends to use the most economical, simple and practical answer to the task. Interestingly, children of 6 and 7 years had lower frequency of D location when compared with children of $8-9$ years $(p=0.013)$, as these children had a tendency to give answers with a less concrete reasoning compared to older.

In short, we observe that when dealing with aspects related to cognitive functioning, children of 6 and 7 years showed reduced ability to establish associations $(\mathrm{R})$, less deliberate thought control $\left(\mathrm{m}_{\mathrm{a}}\right)$ and tendency to a less usual cut of the situations (D, FQu and $\mathrm{Xu} \%$ ). Thus, we believe that this data set could relate to a stage of development where they are still working out some concepts and have not yet completely appropriated cultural influences. Relating to the historical and cultural perspective of development, it can be said that the children in the sample allowed themselves to use their imagination more freely, as they were not restricted to what could be considered socially appropriate or not. According to Vigotski (2005) concept development happens as the child appropriates and objectivates knowledge through the relationships with others, leading to the formation of concepts increasingly objective and relevant to life in society.

The data in Table 2 showed the variables related to Affection and Interpersonal Relationship. The variables $\mathrm{Na}$ and Ls may indicate social isolation, difficulties in social contact outside the family and tendency to withdraw and avoid social contacts, which limits the contact opportunities (Villemor-Amaral \& Primi, 2009). According to Table 2, we realized that these contents are decreased in children of 6 and 7 years. This may mean that children in this age group have sought greater interpersonal relationship, probably because they are in a phase that seeks to recognize the other.

Table 2 also showed that Fd was decreased in children aged 8 and 9 years when compared with children of $10-11$ years $(p=0.029)$. These responses usually show up in the protocols of people who have a dependent conduct and who perceive with certain naivete their interpersonal relationships, waiting for others to take actions for them, such as resolve their demands and solve their own problems (Exner \& Sendin, 1999).

In convergence, Villemor-Amaral and Primi (2009) pointed out that Fd relates to the person tending to present dependent behavior and a naive expectation that others will be tolerant of your needs. This dependence that Fd portrays is more expected in younger children, given that they still have no autonomy to develop and solve their problems, demanding that resoluteness from another, as noted in the study by Villemor-Amaral et al. (2016). The reduction of dependency behaviors (Fd) in children aged 8 and 9 years suggests greater ability to solve their problems.

In Table 2 it can also be seen that $\mathrm{T}$ was increased in children aged 10 and 11 years. When $\mathrm{T}$ appears, even if only in one answer, we are looking at a person who tends to be dependent and to seek support in others (Nascimento, 2010). When we think of affection traits, Exner and Sendín (1999) stated that T relates to the need for physical closeness and emotional contact and when the person seeking this kind of contact experiences feelings of loneliness, abandonment or emotional deprivation, there is a feeling of ill-being. According to these authors, the subject that presents $\mathrm{T}>1$ demonstrates a greater need for closeness and contact, tending to feel more lonely and emotionally dependent on others.

The fact that children aged 10 and 11 years have shown increased $\mathrm{T}$ may be related to the stage of intermediary life between childhood and adolescence. This phase is usually characterized by the need for closer relationships especially with people within the same age range, so they don't feel isolated when going through this phase in life so full of physical, social and psychological changes. In agreement with the data found, the research by Villemor-Amaral et al. (2016) also found increased $T$ in 12 year-old children.

Related to that, we observed that GHR was decreased in children of 6 and 7 years. According to 
Exner (2003, apud Nascimento, 2010) protocols in which a large GHR number is observed tend to belong to people with a history of good interpersonal relationships. The decreased number in the group of younger children can be related to the fact that they are in a phase of development in which the thoughts are more fanciful and not so linked to concrete facts. In a study conducted by Biasi and Villemor-Amaral (2016), the authors sought evidence of Zulliger's validity through the Comprehensive System to evaluate interpersonal relationship indicators. In the end, the GHR indicator, in addition to other indicators, did not show statistically significant differences.

The responses with the variable (2), according to Villemor-Amaral and Primi (2009), are related to the subject's self-image and, according to Nascimento (2010), is one of the components used to calculate the egocentricity index, which refers to how much the subject manages to put himself in the place of the other. It is interesting to observe, in Table 2 , that the number of responses of this type was considerably reduced in the 6 and 7 year olds. In the study by Ribeiro et al. (2011), a low average of response (2) was found in 7-year-old children when compared to the older ones. The fact that this data has been lower in children of 6 and 7 years may be associated with the group being in the initial phase of human development.

We should reiterate that with the values suggested by Benjamin et al. (2017), the only significant variable to differentiate the groups was the FQu (Table 1). This variable differentiated the groups as expected in the literature.

The other variables presented $\mathrm{p}<0.05$ with weak magnitude effect. In this sense, the results obtained should be observed with caution since, on one hand, the data were adequate to differentiate the groups according to the theories of development, on the other hand there is a high statistical probability that at least one type I error occurred.

The variables that could differentiate the groups with $\mathrm{p}<0.05$ were also present in other studies with inkblots (Ribeiro et al., 2011, Resende et al., 2012, Villemor-Amaral et al., 2016) and are in agreement with what is expected in theories of child development, indicating that there is a greater complexity of characteristics linked to psychic functioning as the age increases (Vigotski, 2005; Alberto \& Santos, 2011). Thus, this research corroborates the studies that suggest the ZCS is suitable for use with children (Villemor-Amaral \& Quirino, 2013; Tavella \& Villemor-Amaral, 2014;
Carvalho, 2015; Biasi \& Villemor-Amaral, 2016; Villemor-Amaral et al., 2016; Villemor-Amaral \& Vieira, 2016), reaffirming the possibility of using this method for with children Nunes et al. (2010) defended the importance of such assessments.

This study collaborates with the efforts to find ever safer instruments to assess children at different stages of development (Nascimento et al., 2009). It should be noted, however, that the number of participants in this research is considered small when compared to the parameters established for non-projective tests (CFP, 2003) and the fact that all the participants come from the capital of Ceará, meaning that there is no data from municipalities of the interior of the state. We argue, therefore, that in order to continue seeking evidence of Zulliger's validity for this context, it is necessary to expand the sample size, as well as to involve participants from different cities of the state.

Historically, particularities in researches with projective methods have not been considered an impediment to their realization (Cardoso \& Villemor-Amaral, 2017). Villemor-Amaral (2008) and Miguel (2014) clarify that there is a growing increase in nomothetic studies with projective methods in Brazil, as recommended in the CFP (2003) resolution, and defend the concurrent relevance of idiographic studies, that allow a larger comprehension of the complexity involved in the analysis of these methods.

\section{References}

AERA, APA, \& NCME (2014). Standards for educational and psychological testing. Washington, DC: Author.

Alberto, M. de FP, \& Santos, DP dos. (2011). Trabalho infantil e desenvolvimento: Reflexões à luz de Vigotski. Psicologia em Estudo, 16(2), 209-218. doi: 10.1590/S1413-73722011000200004

Angelini, AL, Alves, ICB, Custódio, EM, Duarte, WF, \& Duarte, JLM (1999). Manual Matrizes Progressivas Coloridas de Raven: escala especial. São Paulo: Centro Editor de Testes e Pesquisas em Psicologia.

Benjamin, DJ, e colaboradores (2017). Redefine statistical significance. Human behaviour, Statistics. Journal Nature Human Behaviour, doi: 10.1038/ s41562-017-0189-z

Biasi, FC, \& Villemor-Amaral, AE (2016). Evidências de validade do Zulliger-SC para avaliação do relacionamento interpessoal de

Psico-USF, Bragança Paulista, v. 23, n. 3, p. 451-460, jul./set. 2018 
crianças. Psico (Porto Alegre), 47(1), 13-23. doi: 10.15448/1980-8623.2016.1.19990

Cardoso, LM \& Villemor-Amaral, AE (2017). Critérios de Cientificidade dos métodos projetivos. Em MRC Lins \& JC Lins (Eds.), Avaliação Psicológica: Aspectos Teóricos e Práticos (pp. 159-172). Petrópolis, RJ: Vozes Editora.

Cartilha da Regional IV. (2011). Mapa da criminalidade e da violência em Fortaleza: Perfil da SER IV. Retrieved from http://www.uece.br/covio/dmdocuments/ regional_IV.pdf

Carvalho, ACM (2015). Normatização do Teste de Zulliger SC para Crianças e Adolescentes (Dissertação de Mestrado). Pontifícia Universidade Católica de Goiás, Goiás.

Conselho Federal de Psicologia - CFP. (2003). Resolução CFP n n $^{\circ}$ 007/2003 - Institui o manual de elaboração de documentos escritos produzidos pelo psicólogo, decorrentes de avaliação psicológica e revoga a Resolução CFP n ${ }^{\circ}$ 17/2002. Retrieved from https://site.cfp.org.br/wp-content/uploads/2003/06/resolucao2003_7.pdf

Exner, JE, \& Sendín, C. (1999). Manual de interpretação do Rorschach para o sistema compreensivo. São Paulo: Casa do Psicólogo.

Field, A. (2009). Descobrindo a estatística usando o SPSS. $2^{\mathrm{a}}$ ed. Porto Alegre: Artmed.

Howell, D. (2009). Statistical Methods for Psychology. $7^{\mathrm{a}} \mathrm{ed}$. UK: Wadsworth.

Miguel, FK (2014). Mitos e verdades no ensino de técnicas projetivas. Psico-USF, 19(1), 97-106. doi: 10.1590/S1413-82712014000100010

Nascimento, RSGF do. (2010). Sistema compreensivo do Rorschach: Teoria, pesquisa e normas para a população brasileira. São Paulo: Casa do Psicólogo.

Nascimento, R., Pedroso, J. da S., \& Souza, AM de. (2009). Método de Rorschach na avaliação psicológica de crianças: Uma revisão de literatura. Psico-USF, 14(2), 193-200. doi: 10.1590/ S1413-82712009000200008

Nunes, MLT, Teixeira, RP, \& Deakin, EK (2010). Técnicas projetivas e avaliação de psicoterapia psicanalítica com crianças. Em MLT Nunes (Ed.), Técnicas Projetivas com crianças (pp.145-170). São Paulo: Casa do Psicólogo.
Oliveira, JC de. (2016). Meninos e meninas: As particularidades dos gêneros no método de Zulliger (Monografia de graduação não publicada). Universidade Estadual do Ceará, Fortaleza - CE.

Reppold, CT, Serafini, AJ, Ramires, DA, \& Gurgel, LG (2017). Análise dos manuais psicológicos aprovados pelo SATEPSI para avaliação de crianças e adolescentes no Brasil. Avaliação Psicológica, 16(1), 19-28. doi: 10.15689/ap.2017.1601.03

Resende, AC, Carvalho, TCR de, \& Martins, W. (2012). Desempenho médio de crianças e adolescentes no Método de Rorschach Sistema Compreensivo. Avaliação Psicológica, 11(3), 375-394. Retrieved from https://goo.gl/cCkoXk

Ribeiro, RKSM, Semer, NL, \& Yazigi, L. (2011). Rorschach Comprehensive System Norms in Brazilian Children from Public and Private Schools. Psicologia: Reflexão e Crítica, 24(4), 671-684. doi: 10.1590/ S0102-79722011000400007

Tavella, RR, \& Villemor-Amaral, AE (2014). O Teste de Zulliger-SC: Avaliação da criatividade em crianças. Estudos de Psicologia (Campinas), 31(4), 489-497. doi: 10.1590/0103-166X2014000400003

Vigotski, LS (2005). Pensamento e linguagem. São Paulo: Martins Fontes.

Villemor-Amaral, AE (2008). A validade teórica em avaliação psicológica. Psicologia: ciência e profissão, 28(1), 98-109. doi: 10.1590/S1414-98932008000100008

Villemor-Amaral, AE, \& Primi, R. (2009). Teste de Zulliger no Sistema Compreensivo - ZSC: Forma individual. São Paulo: Casa do Psicólogo.

Villemor-Amaral, AE, \& Quirino, G. de S. (2013). Estudo comparativo entre indicadores afetivos das técnicas de Pfister e Zulliger. Avaliação Psicológica, 12(1), 1-7. Retrieved from https://goo.gl/FZygjo

Villemor-Amaral, AE, \& Vieira, PG (2016). Zulliger (CS) in Assessing the Relational Maturity of Children. Paidéia, 26(65), 369-376. doi: 10.1590/1982-43272665201601

Villemor-Amaral, AE, Pavan, PMP, Tavella, RR, Cardoso, LM, \& Biasi, FC (2016). Validity Evidence of the Z-Test-SC for Use With Children. Paidéia, 26(64), 199-206. doi: 10.1590/1982-43272664201607

Recebido em: 21/03/2017

Reformulado em: 02/11/2017

Aprovado em: 20/02/2018 
Sobre os autores:

Lucila Moraes Cardoso is an associated professor at the Graduate School of Psychology and Post-Graduation Program in Education at the State University of Ceará (UECE) and collaborator of the post graduate program of the Psychology at the Federal University of Ceará (UECE).

E-mail: lucila.cardoso@uece.br

ORCID: https://orcid.org/0000-0002-8890-9352

Gabriel Vitor Acioly Gomes is Psychologist and Master of Education in Graduate Program in Education from UECE. Currently, is a PhD student in Graduate Program Stricto Sensu from Universidade São Francisco (USF).

E-mail: gabrigom93@hotmail.com

ORCID: http://orcid.org/0000-0001-6565-3094

Thalita Sena Vieira is graduated in Psychology at the State University of Ceará (UECE), was a member of Laboratório de Estudos e Práticas em Avaliação Psicológica (LEAPSI) from UECE.

E-mail: thalytasena18@gmail.com

ORCID: https://orcid.org/0000-0002-0717-7672

Sobre os autores:

A/c Profa. Lucila Moraes Cardoso

Curso de Psicologia

Universidade Estadual do Ceará - UECE

Av. Dr. Silas Munguba, 1700, Campus do Itaperi

Fortaleza-CE, Brasil

CEP: 60714-903 